\title{
A Model Study of the Photochemical Fate of As(III) in Paddy-Water
}

\author{
Luca Carena ${ }^{1}$ and Davide Vione ${ }^{1,2, *}$ \\ 1 Dipartimento di Chimica, Università di Torino, Via Pietro Giuria 5, 10125 Torino, Italy; luca.carena@unito.it \\ 2 Centro Interdipartimentale NatRisk, Università di Torino, Largo Paolo Braccini 2, \\ 10095 Grugliasco (TO), Italy \\ * Correspondence: davide.vione@unito.it; Tel.: +39-011-670-5296
}

Academic Editor: Pierre Pichat

Received: 27 January 2017; Accepted: 6 March 2017; Published: 11 March 2017

\begin{abstract}
The APEX (Aqueous Photochemistry of Environmentally-occurring Xenobiotics) software previously developed by one of us was used to model the photochemistry of As(III) in paddy-field water, allowing a comparison with biotic processes. The model included key paddy-water variables, such as the shielding effect of the rice canopy on incident sunlight and its monthly variations, water $\mathrm{pH}$, and the photochemical parameters of the chromophoric dissolved organic matter (CDOM) occurring in paddy fields. The half-life times $\left(t_{1 / 2}\right)$ of $\mathrm{As}(\mathrm{III})$ photooxidation to $\mathrm{As}(\mathrm{V})$ would be 20-30 days in May. In contrast, the photochemical oxidation of As(III) would be much slower in June and July due to rice-canopy shading of radiation because of plant growth, despite higher sunlight irradiance. At $\mathrm{pH}<8$ the photooxidation of As(III) would mainly be accounted for by reaction with transient species produced by irradiated CDOM (here represented by the excited triplet states ${ }^{3} \mathrm{CDOM}^{*}$, neglecting the possibly more important reactions with poorly known species such as the phenoxy radicals) and, to a lesser extent, with the hydroxyl radicals $\left(\mathrm{HO}^{\bullet}\right)$. However, the carbonate radicals $\left(\mathrm{CO}_{3}{ }^{--}\right)$could be key photooxidants at $\mathrm{pH}>8.5$ provided that the paddy-water ${ }^{3} \mathrm{CDOM}^{*}$ is sufficiently reactive toward the oxidation of $\mathrm{CO}_{3}{ }^{2-}$. In particular, if paddy-water ${ }^{3} \mathrm{CDOM}^{*}$ oxidizes the carbonate anion with a second-order reaction rate constant near (or higher than) $10^{6} \mathrm{M}^{-1} \cdot \mathrm{s}^{-1}$, the photooxidation of $\mathrm{As}(\mathrm{III})$ could be quite fast at $\mathrm{pH}>8.5$. Such $\mathrm{pH}$ conditions can be produced by elevated photosynthetic activity that consumes dissolved $\mathrm{CO}_{2}$.
\end{abstract}

Keywords: arsenic contamination; paddy-field floodwater; sunlight-induced reactions

\section{Introduction}

Arsenic (As) contamination of paddy fields is an important pollution problem in several regions around the world, such as the Bengal Basin area [1]. Contamination by As is usually caused by irrigation of paddy fields with groundwater containing elevated As levels [1,2]. In a paddy field, As can be found both in the soil and in the flooding water, and its concentration range can be quite wide [3]. Moreover, several types of rice plants are able to uptake soil As in the roots and to accumulate it, leading to human exposure through food [3-5]. There are many processes governing As chemistry in paddy fields, which depend on the physicochemical and biological features of paddies and may affect As speciation. The main As redox states are $\mathrm{As}(\mathrm{V})$ and $\mathrm{As}(\mathrm{III})$, usually occurring as inorganic compounds (arsenate and arsenite, respectively) and, to a minor extent, as organic species, such as the methylated As forms [6]. Under aerobic soil conditions that occur before the flooding of rice crops, As is sorbed as $\mathrm{As}(\mathrm{V})$ because the oxyanion arsenate has high affinity for soil minerals and, particularly, for Fe (hydr)oxides. Anaerobic regimes develop into the paddy soil after flooding, and Fe(III) (hydr)oxides and $\mathrm{As}(\mathrm{V})$ undergo fast microbial reduction. Arsenic is, thus, released as As(III) into the soil pore water, because the more mobile (and toxic) As(III) has lesser affinity than $\mathrm{As}(\mathrm{V})$ towards soil minerals [7]. 
The results reported by Takahashi et al. [7] suggest that the half-life time $\left(t_{1 / 2}\right)$ of $\mathrm{As}(\mathrm{V})$ is $\sim 30$ days. The produced aqueous As(III) could subsequently undergo oxidation to $\mathrm{As}(\mathrm{V})$ in the upper soil layers, where oxygen occurs in higher amounts. In particular, biotic oxidation takes place into the oxygenated bulk soil and in the rhizosphere of the rice plant roots, where Fe (hydr)oxides form an iron plaque and As is re-sorbed as $\mathrm{As}(\mathrm{V})[2,8]$. The biotic oxidation of $\mathrm{As}(\mathrm{III})$ occurs mainly as a detoxification process, but As(III) can also be used as an electron/energy source during the growth of microorganisms. Biotic detoxification of $\mathrm{As}(\mathrm{III})$ to $\mathrm{As}(\mathrm{V})$ may be fast, and apparent $t_{1 / 2}$ values have been found to be $<1$ day depending on experimental conditions (although the fastest processes might not always be representative of actual paddies) [9]. As(V) can, in turn, undergo biotic reduction to As(III) in both aerobic and anaerobic environments, by dissimilatory arsenate-reduction processes [10], which may be fast under anaerobic conditions [11]. $\mathrm{As}(\mathrm{V})$ reduction is also fast in aerobic environments, and the $t_{1 / 2}$ of $\mathrm{As}(\mathrm{V})$ has been found to be $<3$ days $[9,12]$. Therefore, microbial oxidation/reduction processes are key phenomena of As speciation in paddy soil and in surface water environments [13]. They could also be important in the paddies floodwater, where light is an important factor as well.

Photochemistry plays a key role in the transformation of inorganic and organic substances in surface water. The photochemical reactions occurring in sunlit natural waters can generally be divided into direct and indirect phototransformation pathways. The direct photolysis of a substrate takes place after absorption of sunlight, if the absorption spectrum of the substance overlaps with the sunlight spectrum. In contrast, indirect photochemistry is triggered by compounds called photosensitizers, which occur naturally in surface waters and are able to absorb sunlight. The main photosensitizers are the chromophoric moieties of dissolved organic matter (chromophoric dissolved organic matter or $\mathrm{CDOM})$, nitrate and nitrite. The irradiated photosensitizers produce high-energy transient species, such as hydroxyl radicals $\left(\mathrm{HO}{ }^{\bullet}\right)$, carbonate radicals $\left(\mathrm{CO}_{3}{ }^{--}\right)$, singlet oxygen $\left({ }^{1} \mathrm{O}_{2}\right)$, and the excited triplet states of $\mathrm{CDOM}\left({ }^{3} \mathrm{CDOM}^{*}\right)$. These transient species react with dissolved substrates and cause their indirect phototransformation [14]. As(III) is well known to react with both $\mathrm{HO}^{\bullet}$ and ${ }^{3} \mathrm{CDOM}^{*}$ [15-18], whereas its reactivity with carbonate radicals has been studied only under alkaline conditions [15]. As(III) reactivity toward ${ }^{1} \mathrm{O}_{2}$ was found to be negligible in solutions containing humic substances under irradiation [18]. Direct As(III) photolysis could occur significantly at $\lambda=254 \mathrm{~nm}$ [19], but it is not an important photochemical pathway under sunlight [16,17].

It should be pointed out that the oxidation of $\mathrm{As}(\mathrm{III})$ in the presence of irradiated CDOM likely involves radical species (presumably phenoxy radicals) to a higher extent than ${ }^{3} \mathrm{CDOM}^{*}$ [18]. Unfortunately, little to nothing is known about the formation and reactivity of these radicals, which prevents photochemical modelling. In the present study, the photochemical fate of As(III) in rice-field water was modelled using the available literature values of the second-order rate constants of the reactions between $\mathrm{As}(\mathrm{III})$ and several transients $\left({ }^{\bullet} \mathrm{OH},{ }^{3} \mathrm{CDOM}^{*}, \mathrm{CO}_{3}{ }^{\bullet-}\right)$, as well as the photochemical parameters of paddy floodwater. This approach provides a lower limit for the photochemical oxidation kinetics of As(III), by neglecting the reactions involving the phenoxy radicals.

\section{Results and Discussion}

The half-life time $\left(t_{1 / 2}\right)$ of $\mathrm{As}(\mathrm{III})$, in the form of $\mathrm{H}_{3} \mathrm{AsO}_{3}$, in sunlit rice field water was modelled for the months of May, June, and July. This period follows the flooding of paddies in late April-early May. The details of the photochemical model are reported in the Methods section. Figure 1a,b show the half-life times of $\mathrm{H}_{3} \mathrm{AsO}_{3}$ in May and June as a function of nitrate concentration and of the dissolved organic carbon (DOC) content of paddy water. The light transmittance through the rice plant canopy was taken into account in the model, considering that the canopy shading effect increases as the rice plants grow higher. Consequently, during the rice growing season there can be considerable variations in the sunlight irradiance that reaches the paddy-water surface [20]. Sunlight transmittance through the rice canopy has been measured in the La Albufera coastal lagoon (Spain, latitude $\sim 39^{\circ} \mathrm{N}$ ) during the months of May, June, and July, 1989 [21]. The reported monthly values of the average transmittance 
were $\sim 53 \%, \sim 8 \%$ and $\sim 6 \%$, respectively. These values were used to model As(III) photochemistry in the present work.

It can be seen from Figure 1 that $t_{1 / 2}$ undergoes important variations with nitrate concentration and DOC. In particular, at low DOC values $\left(<1 \mathrm{mg} \cdot \mathrm{C} \cdot \mathrm{L}^{-1}\right)$ the increase of nitrate causes a significant $t_{1 / 2}$ decrement, because in such conditions $\mathrm{HO}^{\bullet}$ that is partially photogenerated by nitrate plays a major role in $\mathrm{As}$ (III) photochemical oxidation (see also Figure 2a, which reports the fraction of $\mathrm{H}_{3} \mathrm{AsO}_{3}$ oxidized by $\mathrm{HO}^{\bullet}$ as a function of DOC and nitrate). Low-DOC conditions are scarcely representative of the rice field floodwater environment, however, because a significant amount of dissolved organic matter (DOM, not necessarily chromophoric) is released by soil/sediment and by the rice plants. When the DOC is higher $\left(>6 \mathrm{mg} \cdot \mathrm{C} \cdot \mathrm{L}^{-1}\right.$, more representative of paddy floodwater), nitrate has a limited influence on the rate of As(III) photooxidation. Under these circumstances CDOM is the main chromophore, it limits the sunlight absorption by nitrate and it is also the main photochemical $\mathrm{HO}^{\bullet}$ source. Moreover, DOM (note that high-DOC waters are DOM-rich by definition [22]) is a major $\mathrm{HO}{ }^{\bullet}$ scavenger and causes the steady-state $\left[\mathrm{HO}^{\bullet}\right]$ to be low. In contrast, $\left[3 \mathrm{CDOM}^{*}\right]$ is higher at high DOC [14] and, in these circumstances, the triplet-sensitised processes can play an important role in As(III) photooxidation (see Figure $2 \mathrm{~b}$ ). The maximum values of $t_{1 / 2}$ occur at DOC $=1-2 \mathrm{mg} \cdot \mathrm{C} \cdot \mathrm{L}^{-1}$ (Figure 1). In these conditions, there is already enough DOM to scavenge $\mathrm{HO} \bullet$ significantly, but not yet enough CDOM to produce elevated [3CDOM*].

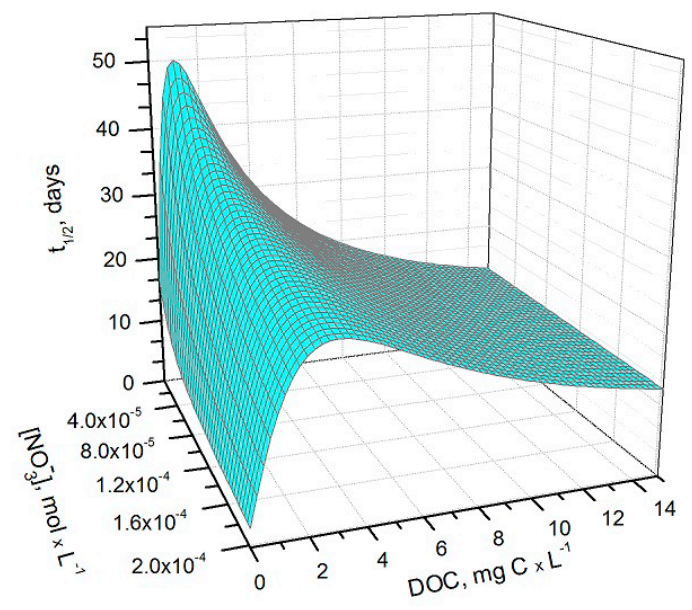

(a)

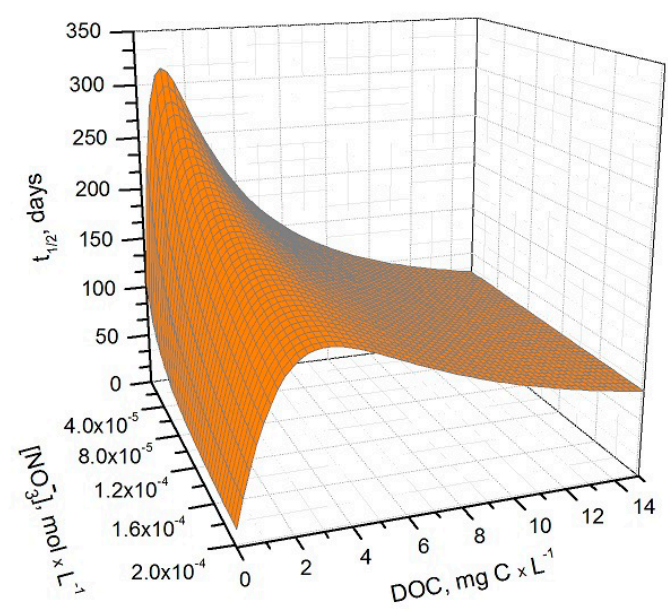

(b)

Figure 1. (a) Photochemical half-life time $\left(t_{1 / 2}\right)$ of $\mathrm{H}_{3} \mathrm{AsO}_{3}$ in rice field water in May. Water conditions: $5 \mathrm{~cm}$ depth; $1 \mu \mathrm{M} \mathrm{NO}_{2}{ }^{-}, 1 \mathrm{mM}$ bicarbonate, $10 \mu \mathrm{M}$ carbonate, and 0.53 sunlight transmittance; (b) Photochemical half-life time of $\mathrm{H}_{3} \mathrm{AsO}_{3}$ in rice field water in June. Water conditions: $5 \mathrm{~cm}$ depth; $1 \mu \mathrm{M} \mathrm{NO}_{2}{ }^{-}, 1 \mathrm{mM}$ bicarbonate, $10 \mu \mathrm{M}$ carbonate and 0.08 sunlight transmittance. The day units of $t_{1 / 2}$ are referred to average mid-latitude irradiance conditions occurring in mid-May and mid-June, respectively.

It is interesting to note that the $t_{1 / 2}$ values are lower in May than in June, despite the significantly higher sunlight irradiance in June [14]. The reason is that the rice plants are higher in June, and their canopy produces a considerable decrease of the irradiance over the water surface. The shading by the rice canopy deeply affects all the photochemical processes as shown in Figure 3a, which reports the $t_{1 / 2}$ of $\mathrm{As}(\mathrm{III})$ as a function of water DOC and canopy transmittance. Figure $3 \mathrm{~b}$ shows the overall $\mathrm{As}(\mathrm{III})$ photooxidation kinetics in May through July, which is affected both by sunlight irradiance and by shading from the rice canopy. It is clear that photooxidation is faster in May, while limited differences can be observed between June and July. Photochemical processes are predicted to be quite slow in June and July due to canopy shading. In contrast, the value $t_{1 / 2} \sim 20$ days in May is, interestingly, of the same order of magnitude as the As(III) level fluctuations observed in a laboratory experiment 
that used paddy water and soil [7]. As(III) photooxidation may, thus, potentially play a role in As processing in paddy fields in the month of May, but in definite circumstances it has been found that the As redox processes in paddy soil and in the rice rhizosphere may be considerably faster $[8,9,12]$.

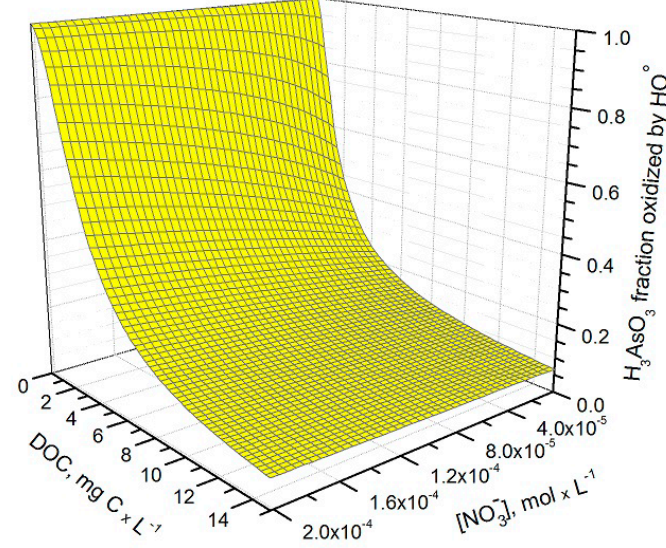

(a)

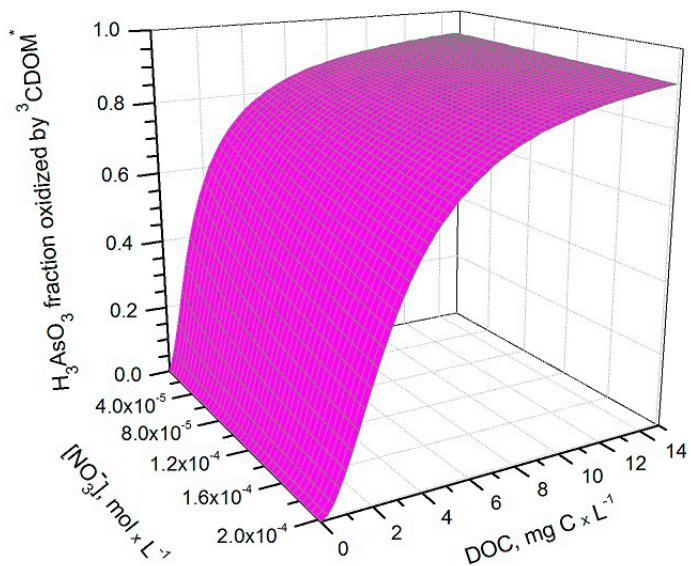

(b)

Figure 2. Fraction of $\mathrm{H}_{3} \mathrm{AsO}_{3}$ transformed by (a) hydroxyl radicals and (b) CDOM triplet states $\left({ }^{3} \mathrm{CDOM}^{*}\right)$ in May, as a function of nitrate and dissolved organic carbon (DOC). Water conditions: $5 \mathrm{~cm}$ depth, $1 \mu \mathrm{M} \mathrm{NO}_{2}{ }^{-}, 1 \mathrm{mM}$ bicarbonate, and $10 \mu \mathrm{M}$ carbonate. Note that direct photolysis, carbonate radicals and singlet oxygen reactions were not taken into account in the model.

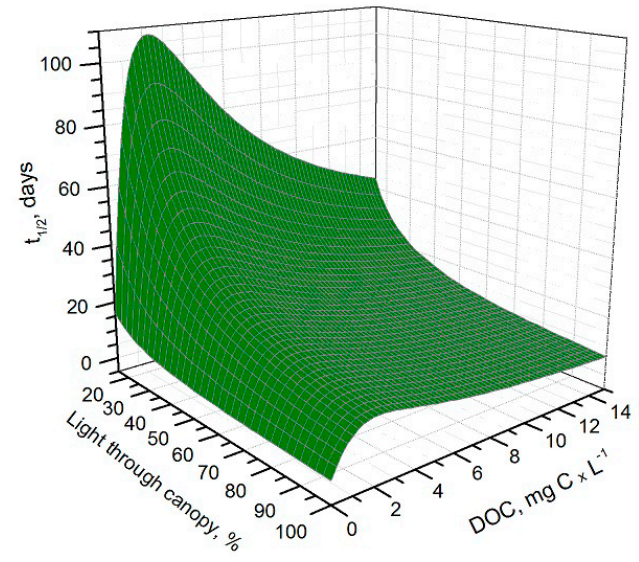

(a)

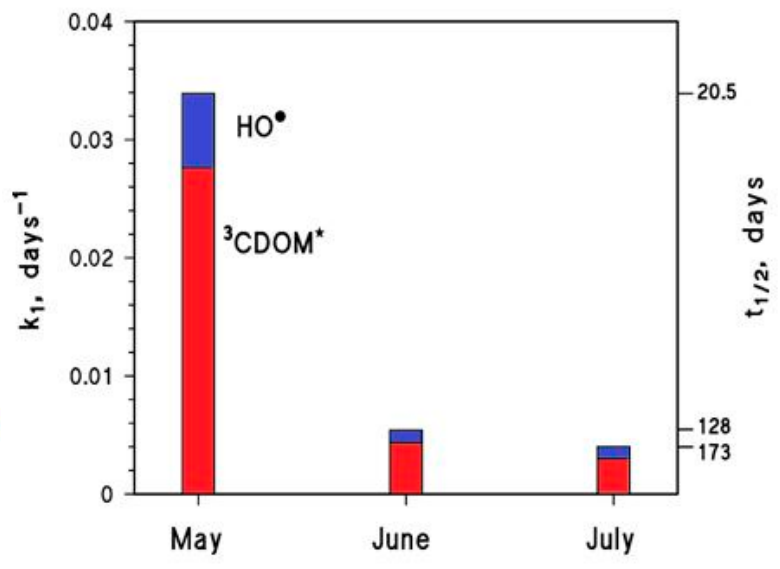

(b)

Figure 3. (a) Photochemical half-life time of $\mathrm{H}_{3} \mathrm{AsO}_{3}$ in rice-field water, as a function of the DOC and of light transmittance through the rice canopy. Other conditions: $5 \mathrm{~cm}$ depth, $0.1 \mathrm{mM} \mathrm{NO}_{3}{ }^{-}, 1 \mu \mathrm{M}$ $\mathrm{NO}_{2}{ }^{-}, 1 \mathrm{mM}$ bicarbonate, $10 \mu \mathrm{M}$ carbonate, and May sunlight. (b) Pseudo-first-order rate constant of $\mathrm{H}_{3} \mathrm{AsO}_{3}$ photooxidation in the period from May to July. The corresponding half-life times $\left(t_{1 / 2}=\ln 2\right.$ $\left(k_{1}\right)^{-1}$ ) are also reported in the right Y-axis. Water conditions: $5 \mathrm{~cm}$ depth, $7 \mathrm{mg} \cdot \mathrm{C} \cdot \mathrm{L}^{-1} \mathrm{DOC}, 0.1 \mathrm{mM}$ $\mathrm{NO}_{3}{ }^{-}, 1 \mu \mathrm{M} \mathrm{NO}_{2}{ }^{-}, 1 \mathrm{mM}$ bicarbonate, and $10 \mu \mathrm{M}$ carbonate. Transmittance values through the rice canopy are reported in the main text. The days are referred to average irradiance conditions occurring at mid latitude in, where relevant, mid-May, mid-June, and mid-July.

Under DOC conditions that are typically representative of paddy water, such as those assumed in the modelling of Figure $3 \mathrm{~b},{ }^{3} \mathrm{CDOM}^{*}$ would be the main photooxidant for As(III) and account for $\sim 80 \%$ of its transformation, while the remaining $\sim 20 \%$ could be ascribed to $\mathrm{HO}^{\bullet}$. This finding is consistent with the experimental results reported by Buschmann et al. in irradiation experiments of As(III) solutions containing humic substances [18], where the role of $\mathrm{HO}^{\bullet}$ in As(III) phototransformation was 
a minor one. Note that the relative importance of ${ }^{3} \mathrm{CDOM}^{*}$ and $\mathrm{HO}{ }^{\bullet}$ in $\mathrm{As}(\mathrm{III})$ photooxidation does not depend on the light transmittance through the rice canopy, but it is rather a function of the water chemistry. Moreover, it should be recalled here that the reaction between As(III) and ${ }^{3} \mathrm{CDOM}^{*}$ is only a lower limit for the reaction kinetics between As(III) and irradiated CDOM, because the main oxidative process is actually carried out by additional transients (possibly phenoxy radicals) [18].

The above discussion refers to photochemical scenarios in which $\mathrm{HO}^{\bullet}$ and ${ }^{3} \mathrm{CDOM}^{*}$ are assumed to be the main photooxidants of $\mathrm{As}(\mathrm{III})$. However, $\mathrm{H}_{3} \mathrm{AsO}_{3}$ is in equilibrium with its conjugate base $\mathrm{As}(\mathrm{OH})_{2} \mathrm{O}^{-}\left(\mathrm{pK}_{\mathrm{a}}=9.2\right)$, for which the photoreactivity has been studied in basic conditions only [15]. To carry out a more complete description of As(III) indirect photochemistry, $\mathrm{pH}$ was included into the model (see Methods for the mathematical treatment). By considering $\mathrm{pH}$ as a master variable and introducing the photoreactivity of $\mathrm{As}(\mathrm{OH})_{2} \mathrm{O}^{-}$, the role of $\mathrm{CO}_{3}{ }^{\bullet-}$-induced oxidation gains importance as a photochemical process. The radical $\mathrm{CO}_{3}{ }^{\bullet-}$ is produced by bicarbonate and carbonate oxidation (Reactions 1-3), and the corresponding second-order reaction rate constants are $k_{\mathrm{HCO}_{3}^{-}}^{\mathrm{HO}}=8.5 \cdot 10^{6} \mathrm{M}^{-1}$ $\mathrm{s}^{-1}, k_{\mathrm{CO}_{3}^{2-}}^{\mathrm{HO}}=3.9 \cdot 10^{8} \mathrm{M}^{-1} \mathrm{~s}^{-1}$, as well as $k_{\mathrm{CO}_{3}^{3}{ }^{2-} M^{*}}$. In particular, we found that the reactivity of ${ }^{3} \mathrm{CDOM}^{*}$ with the carbonate anions (expressed by the parameter $\mathrm{k}_{\mathrm{CO}_{3}^{2-}}^{3} \mathrm{CDOM}^{*}$, see Reaction 3) is a key variable of the model. The value of $k_{\mathrm{CO}_{3}^{2-}}^{3} \mathrm{CDOM}^{*}$ has been found to vary widely depending on the proxy molecules (triplet sensitizers) used to study the reactivity between $\mathrm{CO}_{3}{ }^{2-}$ and ${ }^{3} \mathrm{CDOM}^{*}$ [23].

$$
\begin{gathered}
\mathrm{HO}^{\bullet}+\mathrm{HCO}_{3}-\stackrel{k_{\mathrm{HCO}_{3}^{-}}^{\mathrm{HO}}}{\longrightarrow} \mathrm{H}_{2} \mathrm{O}+\mathrm{CO}_{3}^{\bullet-} \\
\mathrm{HO}^{\bullet}+\mathrm{CO}_{3}{ }^{2-} \stackrel{{ }^{\mathrm{HO}} \mathrm{CO}_{3}^{2-}}{\longrightarrow} \mathrm{HO}^{-}+\mathrm{CO}_{3}^{\bullet-} \\
{ }^{3} \mathrm{CDOM}^{*}+\mathrm{CO}_{3}{ }^{2-} \stackrel{k^{3} \mathrm{CDOM}_{3}^{2-}}{\longrightarrow} \mathrm{CDOM}^{\bullet-}+\mathrm{CO}_{3}^{\bullet-}
\end{gathered}
$$

Figure 4a shows how the $\mathrm{pH}$ and the $\mathrm{k}_{\mathrm{CO}_{3}^{3-}}^{3 \mathrm{CDOM}^{*}}$ rate constant values affect the half-life time of As(III) in paddy floodwater in May. For $\mathrm{pH}<8, k_{\mathrm{CO}_{3}^{2-}}^{3} \mathrm{CDOM}^{*}$ and $\mathrm{pH}$ have a scarce influence on As(III) photochemistry and one has $t_{1 / 2} \sim 20$ days, in analogy with the results reported in Figures 1 and 3. In this scenario, As(III) photooxidation would be mainly accounted for by the reactions between $\mathrm{H}_{3} \mathrm{AsO}_{3}$ and ${ }^{3} \mathrm{CDOM}^{*} / \mathrm{HO}^{\bullet}$ (see also Figure 4c, which reports the fractions of As(III) photooxidation accounted for by $\mathrm{HO}^{\bullet}, \mathrm{CO}_{3}^{\bullet-}$, and ${ }^{3} \mathrm{CDOM}^{*}$, for different values of $\mathrm{pH}$ and of $k_{\mathrm{CO}_{3}^{2-}} \mathrm{CDOM}^{*}$ ). Indeed, the molar fraction of $\mathrm{As}(\mathrm{OH})_{2} \mathrm{O}^{-}\left(\alpha_{\mathrm{As}(\mathrm{OH})_{2} \mathrm{O}^{-}}\right.$, see the Methods section) and the steady-state $\left[\mathrm{CO}_{3}{ }^{\bullet-}\right]$ (Figure $4 \mathrm{~b}$ ) are too low at $\mathrm{pH}<8$ for $\mathrm{CO}_{3}{ }^{\circ-}$ to be involved significantly in As(III) oxidation.

At $\mathrm{pH}>8-8.5$ one has different trends depending on the value of $\mathrm{K}_{\mathrm{CO}_{3}^{2-}}^{\mathrm{CDOM}^{*}}$. If $k_{\mathrm{CO}_{3}^{3-} \mathrm{CDOM}^{*}}$ is below $10^{6} \mathrm{M}^{-1} \cdot \mathrm{s}^{-1}, t_{1 / 2}$ has some increase with increasing $\mathrm{pH}$ (Figure $4 \mathrm{a}$ ), because $\left[\mathrm{CO}_{3}^{\bullet-}\right]$ is too low in these conditions (see Figure $4 \mathrm{~b}$ ) to significantly affect the photooxidation of $\mathrm{As}(\mathrm{III})$, and because $\mathrm{As}(\mathrm{OH})_{2} \mathrm{O}^{-}$ is less reactive than $\mathrm{H}_{3} \mathrm{AsO}_{3}$ towards $\mathrm{HO}^{\bullet}$ and ${ }^{3} \mathrm{CDOM}^{*}[15,18]$. In this case, the photooxidation of $\mathrm{H}_{3} \mathrm{AsO}_{3}$ prevails as the $\mathrm{As}(\mathrm{III})$ transformation process (see Figure $4 \mathrm{c}$ ). In contrast, if $k_{\mathrm{CO}_{3}^{3} \mathrm{CDOM}^{*}}$ is around $10^{6} \mathrm{M}^{-1} \cdot \mathrm{s}^{-1}$ or higher, one has an important decrease of $t_{1 / 2}$ with increasing $\mathrm{pH}$. The main reason is the reaction between $\mathrm{As}(\mathrm{OH})_{2} \mathrm{O}^{-}$and $\mathrm{CO}_{3}{ }^{\bullet-}$ (see Figure 4c), which is enhanced by the parallel increase with $\mathrm{pH}$ of both $\alpha_{\mathrm{As}(\mathrm{OH})_{2} \mathrm{O}^{-}}$and $\left[\mathrm{CO}_{3}{ }^{\bullet-}\right]$. 


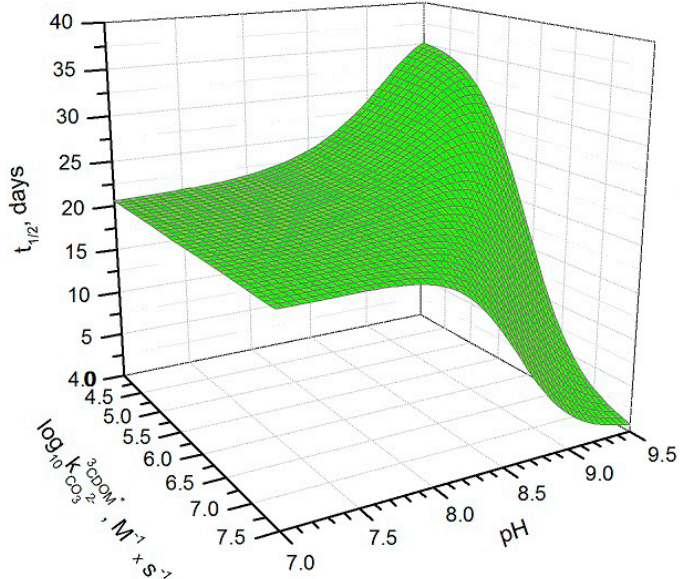

(a)

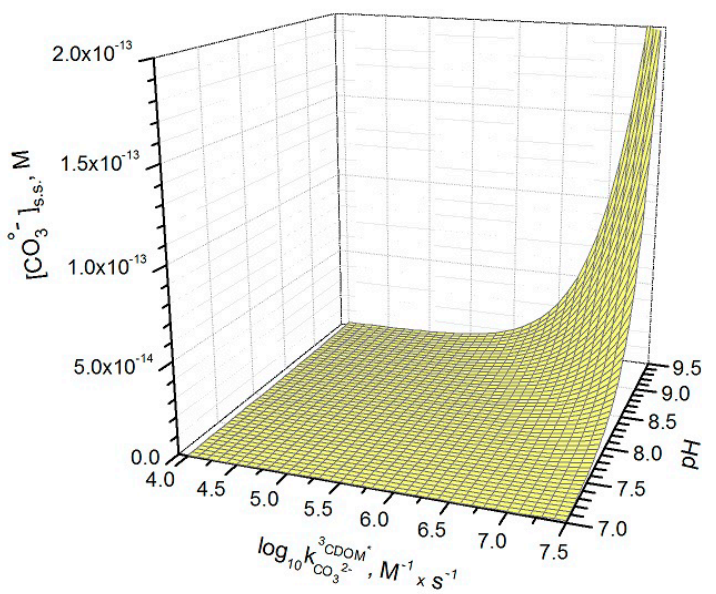

(b)

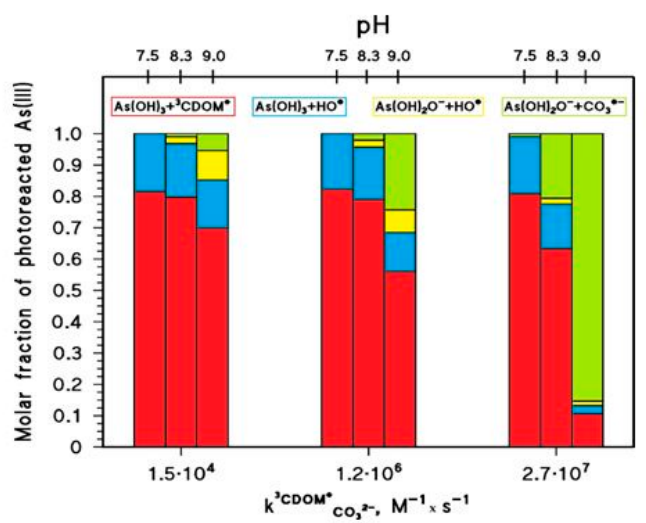

(c)

Figure 4. Photochemical parameters of $\mathrm{As}(\mathrm{III})$ photooxidation computed for the month of May. Water conditions: $5 \mathrm{~cm}$ depth, $0.1 \mathrm{mM} \mathrm{NO}_{3}{ }^{-}, 1 \mu \mathrm{M} \mathrm{NO}_{2}{ }^{-}$, inorganic carbon (IC) $=1.1 \mathrm{mmol} \cdot \mathrm{C} \cdot \mathrm{L}^{-1}$, and DOC $=7 \mathrm{mg} \cdot \mathrm{C} \cdot \mathrm{L}^{-1}$. (a) Half-life time of As(III) and (b) steady-state concentrations of the carbonate radicals, as a function of $\mathrm{pH}$ and of the decimal logarithm of $\mathrm{K}_{\mathrm{CO}_{3}^{3-}}^{3 \mathrm{CDOM}^{*}}$. The days are referred to average irradiance conditions occurring at mid-latitude in mid-May. (c) Roles of the main reactions accounting for the photooxidation of dissolved $\mathrm{As}(\mathrm{III})$. The $\mathrm{k}_{\mathrm{CO}_{3}^{2-}}^{3 \mathrm{CDOM}^{*}}$ values used in (c) are those reported for the three CDOM proxy molecules $3^{\prime}$-methoxyacetophenone $\left(1.5 \cdot 10^{4} \mathrm{M}^{-1} \cdot \mathrm{s}^{-1}\right)$, benzophenone $\left(1.2 \cdot 10^{6} \mathrm{M}^{-1} \cdot \mathrm{s}^{-1}\right)$ and duroquinone $\left(2.7 \cdot 10^{7} \mathrm{M}^{-1} \cdot \mathrm{s}^{-1}\right)$ [23].

The $\mathrm{pH}$ increase of $\left[\mathrm{CO}_{3}{ }^{--}\right]$shown in Figure $4 \mathrm{~b}$ is mainly due to the reaction between $\mathrm{CO}_{3}{ }^{2-}$ and ${ }^{3} \mathrm{CDOM}^{*}$, and it is expected to occur only if $k_{\mathrm{CO}_{3}^{3} \mathrm{CDOM}^{*}}^{2} \sim 10^{6} \mathrm{M}^{-1} \cdot \mathrm{s}^{-1}$ or higher. The important role of $k_{\mathrm{CO}_{3}^{3}}^{3 \mathrm{CDOM}^{*}}$ is additionally highlighted in Figure $5 \mathrm{a}$, which reports the relative weight of the various

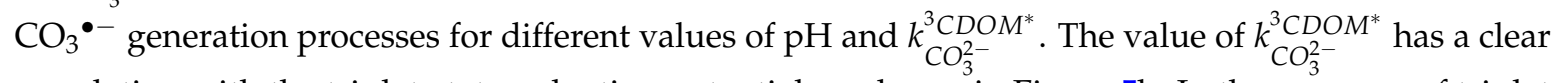
correlation with the triplet-state reduction potential, as shown in Figure 5b. In the presence of triplet states with sufficiently high oxidizing power (e.g., $\mathrm{E}^{\circ}\left({ }^{3} \mathrm{CDOM}^{*} / \mathrm{CDOM}^{\bullet-}\right)>1.7 \mathrm{~V}$, causing significant $\mathrm{CO}_{3}{ }^{--}$production) and at basic $\mathrm{pH}, t_{1 / 2}$ could reach very low values (below one week) and make photochemistry a very significant factor in the As redox cycling. 


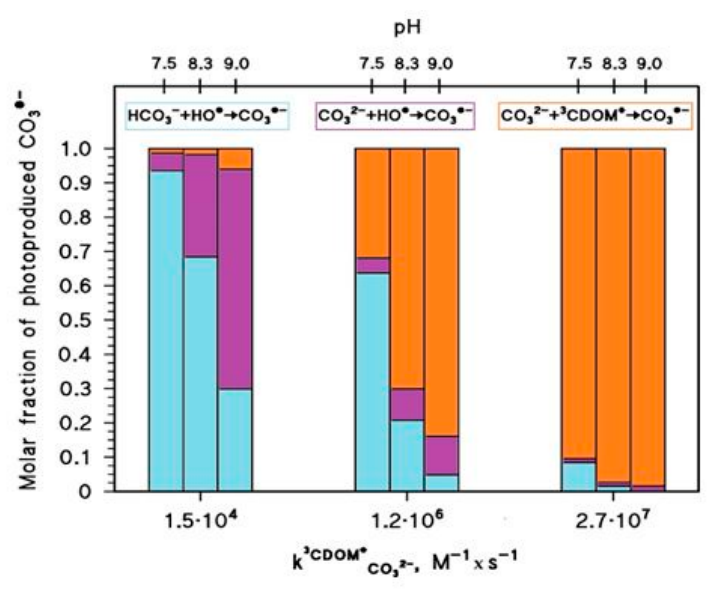

(a)

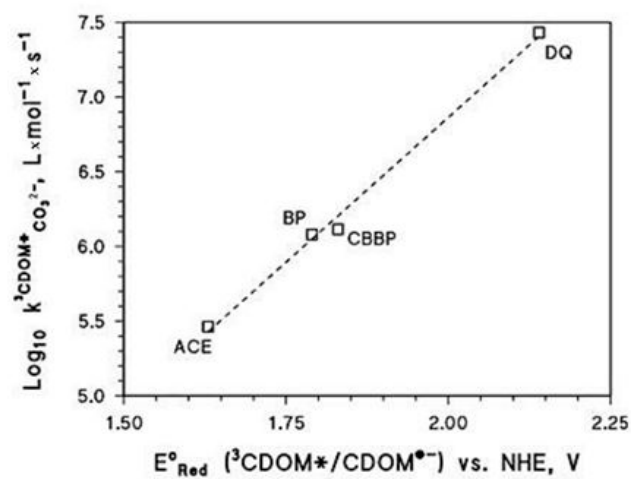

(b)

Figure 5. (a) Relative contributions of Reactions $1-3$ to the production of $\mathrm{CO}_{3}{ }^{\bullet-}$ in the scenario described by Figure 4. (b) Correlation plot between the reduction potentials of some excited triplet states and their reactivity toward the carbonate anion, expressed as second-order reaction rate constants: $\mathrm{ACE}$ = acetophenone; $\mathrm{BP}=$ benzophenone; $\mathrm{CBBP}=4$-carboxybenzophenone; $\mathrm{DQ}=$ duroquinone. The $k_{\mathrm{CO}_{3}^{3}}^{3} \mathrm{CDOM}^{*}$ values used are those reported in [23].

In the presence of sufficiently reactive ${ }^{3} \mathrm{CDOM}^{*}$, favourable $\mathrm{pH}$ conditions for $\mathrm{As}(\mathrm{III})$ photooxidation could be produced by algal photosynthesis that consumes dissolved $\mathrm{CO}_{2}$ and may considerably increase the water $\mathrm{pH}$. The reaction rate constants between paddy-field ${ }^{3} \mathrm{CDOM}^{*}$ and $\mathrm{CO}_{3}{ }^{2-}$ are presently unknown and the topic deserves further investigation, but the occurrence of humic substances in paddy water [24] may suggest a non-negligible photoreactivity of the relevant CDOM [25].

\section{Methods (Photochemical Modelling)}

The assessment of As(III) photooxidation was carried out with the APEX Aqueous Photochemistry of Environmentally-occurring Xenobiotics) software, which is freely available as electronic supplementary information of [26]. APEX allows for the modelling of the photochemistry of surface-water environments (in the form of steady-state concentrations of photogenerated transients) and of the photochemical fate of xenobiotics. APEX computes the xenobiotics pseudo-first-order transformation rate constants $\left(k_{1}\right)$ and half-life times $\left(t_{1 / 2}=\ln 2\left(k_{1}\right)^{-1}\right)$ [26] as a function of sunlight irradiance, water (photo)chemistry, and depth. For this purpose, APEX has been used successfully to investigate the photochemical behaviour of several xenobiotics and the formation of their phototransformation intermediates [27-30]. APEX requires input data concerning water depth, chemical composition (nitrate, nitrite, dissolved organic carbon, and inorganic carbon species) and photochemistry (absorption spectrum and formation quantum yields of transient species by CDOM). Moreover, second-order reaction rate constants with the photogenerated transients and photolysis quantum yields are key parameters to model the photochemical fate of xenobiotics.

APEX uses as standard sunlight irradiance and standard sunlight spectrum the quantities relative to fair-weather 15 July at mid latitude $\left(45^{\circ} \mathrm{N}\right)$, at 9 a.m. or 3 p.m. solar time. It also allows an approximate assessment of photochemistry throughout the year thanks to the APEX_season function, which operates corrections in order to compute transient steady-state concentrations and photoreaction kinetics in different months. However, APEX does not automatically take into account the effect of sunlight shielding by the rice plant canopy. The photochemistry of paddy floodwater occurs during the rice-growing season from May to July, and the shielding effect was included in the model by considering the transmittance $(T)$ of sunlight through the plant canopy in each month (i.e., literature-available $T^{\text {month }}$, where month is May, June or July). Be $k_{1}^{\text {month }}$ the APEX-modelled 
photooxidation kinetics (first-order decay constant) of As(III) without taking into account the shielding effect. The correction was carried out by computing $\left(k_{1}^{\text {month }}\right) \prime=k_{1}^{\text {month }} \times T^{\text {month }}$. It must be pointed out that $T^{\text {month }}$ was considered to be wavelength-independent, which is justified by the fact that the size of the shielding medium (plant leaves and stems) is much longer than the light wavelengths. Another key input parameter in the model is the water depth, $d$. Depth, together with the solar zenith angle $(z)$, influences the optical path length of sunlight into the water. Here, a value of $5 \mathrm{~cm}$ was assumed for the water depth, which is typical of paddy fields in May and undergoes some non-substantial increase in the following months. By considering a constant water depth one slightly overestimates the photochemistry in June and July, but calculations showed that photochemical reactions would, in any case, be negligible in these months due to light shielding by the rice canopy. The light optical path length $l$ was obtained as $l=d\left[{\sqrt{\left(1-\left(n^{-1} \times \sin z\right)^{2}\right.}}^{-1}\right.$, where $n=1.34$ is the refraction index of water and $z$ is the zenith angle. As a result, $l>d$ was $6 \mathrm{~cm}$ in May and $5.7 \mathrm{~cm}$ in June and July [26].

The chemical and photochemical parameters of paddy water have been set in analogy with the results of previous work [24], carried out on paddy-water samples from three rice farms located in the province of Vercelli (Piedmont region, northwestern Italy). In particular, the average formation quantum yields of the transient species $i$ from irradiated $C D O M\left(\Phi_{i}^{C D O M}\right)$ had the following values: $\Phi_{H O^{*}}^{C D O M}=1.7 \cdot 10^{-5} ; \Phi_{3}^{C D O M}{ }^{C D O M} M^{*}=2.9 \cdot 10^{-2}$, and $\Phi_{{ }_{1} O_{2}}^{C D O M}=9 \cdot 10^{-3}$. The chemical analysis of the paddy water samples yielded on average DOC $\sim 7 \mathrm{mg} \cdot \mathrm{C} \cdot \mathrm{L}^{-1}$ and inorganic carbon (IC) $\sim 13 \mathrm{mg} \cdot \mathrm{C} \cdot \mathrm{L}^{-1}$ (namely, $\left.\sim 10^{-3} \mathrm{~mol} \cdot \mathrm{C} \cdot \mathrm{L}^{-1}\right)$. Nitrate and nitrite were under the limit of detection in two out of three samples, the third one having $1.7 \mathrm{mg} \cdot \mathrm{N} \cdot \mathrm{L}^{-1}$ nitrate and $18 \mu \mathrm{g} \cdot \mathrm{N} \cdot \mathrm{L}^{-1}$ nitrite (namely, $1.2 \mathrm{mmol} \cdot \mathrm{L}^{-1}$ nitrate and $1.3 \mu \mathrm{mol} \cdot \mathrm{L}^{-1}$ nitrite). Similar values of nitrate concentration have been reported for flooded paddy fields in Spain [21].

The modelling of As(III) photochemistry was initially carried out by considering the reactions of $\mathrm{H}_{3} \mathrm{AsO}_{3}$ with $\mathrm{HO}^{\bullet}$ and ${ }^{3} \mathrm{CDOM}^{*}$, for which the following second-order rate constants were used: $k_{\mathrm{H}_{3} \mathrm{AsO}_{3}}^{\mathrm{HO}_{3}}=8.5 \cdot 10^{9} \mathrm{M}^{-1} \cdot \mathrm{s}^{-1}[15,16]$, and $k_{\mathrm{H}_{3} \mathrm{CSO}_{3}}^{3}=1.6 \cdot 10^{7} \mathrm{M}^{-1} \cdot \mathrm{s}^{-1}$ [18]. The reaction of As(III) with $\mathrm{HO}^{\bullet}$ forms an $\mathrm{As}(\mathrm{IV})$ species that is quite unstable under aerated conditions and is quickly oxidized to $\operatorname{As}(\mathrm{V})$ upon reaction with dissolved oxygen, following different possible pathways $[15,16]$. Since paddy water is oxygen-rich during the day due to photosynthesis [31,32], we considered the reaction between $\mathrm{As}(\mathrm{IV})$ and $\mathrm{O}_{2}$ to be very fast and assumed the oxidation of $\mathrm{As}(\mathrm{III})$ by $\mathrm{HO}^{\bullet}$ to be the rate-determining step of $\mathrm{As}(\mathrm{V})$ production.

The reactivity of $\mathrm{As}(\mathrm{III})$ with $\mathrm{CO}_{3}{ }^{\bullet-}$ has been investigated in the literature only in basic conditions $(\mathrm{pH}>9)$, and the second-order rate constant has been reported as $k_{\mathrm{As}(\mathrm{OH})_{2} \mathrm{O}^{-}}^{\mathrm{CO}^{--}}=1.1 \cdot 10^{8} \mathrm{M}^{-1} \cdot \mathrm{s}^{-1}$ [15]. Since $\mathrm{H}_{3} \mathrm{AsO}_{3}$ has $\mathrm{pK}_{\mathrm{a}}=9.2$, the reaction between $\mathrm{CO}_{3}{ }^{\bullet-}$ and $\mathrm{As}(\mathrm{OH})_{2} \mathrm{O}^{-}$should be important only at basic $\mathrm{pH}$ where $\mathrm{As}(\mathrm{OH})_{2} \mathrm{O}^{-}$is a significant $\mathrm{As}(\mathrm{III})$ species. Singlet oxygen has been found to react slowly with As(III) [18], and it was thus neglected in our model. It must be pointed out that phenoxy radicals, produced by CDOM irradiation, could be key photooxidants of As(III) [18]. Unfortunately, these reactive species are very difficult to take into account in a photochemical model because of insufficient knowledge concerning the amount of phenolic domains in DOM and their possible variability in different environments. Moreover, the formation quantum yields of phenoxy radicals and their second-order rate constants with xenobiotics are not known. For this reason, the present photochemical model did not take into account the oxidation of As(III) by phenoxy radicals. Therefore, the photochemistry of As(III) in rice field water might be underestimated.

The photochemical pseudo-first order rate constants of As(III) oxidation were also modelled as a function of water $\mathrm{pH}$, by assuming that the total concentration of dissolved As(III) (namely, [As(III) $]_{\text {tot }}$ ) is the sum of $\left[\mathrm{H}_{3} \mathrm{AsO}_{3}\right]$ and $\left[\mathrm{As}(\mathrm{OH})_{2} \mathrm{O}^{-}\right]$. Each concentration can be expressed as a function of [As(III) $]_{\text {tot }}$ and $\mathrm{pH}$, by using the molar fractions $\alpha_{\mathrm{x}}$ (where $x=\mathrm{H}_{3} \mathrm{AsO}_{3}$ or $\mathrm{As}(\mathrm{OH})_{2} \mathrm{O}^{-}$):

$$
\left[H_{3} A s O_{3}\right]=[A s(I I I)]_{t o t} \alpha_{H_{3} A s O_{3}}=[A s(I I I)]_{t o t} \frac{\left[H^{+}\right]}{\left[H^{+}\right]+K_{a}}
$$




$$
\left[A s(\mathrm{OH})_{2} \mathrm{O}^{-}\right]=[A s(\mathrm{III})]_{t o t} \alpha_{A s(\mathrm{OH})_{2} \mathrm{O}^{-}}=[A s(I I I)]_{t o t} \frac{K_{a}}{\left[H^{+}\right]+K_{a}}
$$

The photochemical reactions taken into account are listed below:

$$
\begin{gathered}
\mathrm{H}_{3} \mathrm{AsO}_{3} \stackrel{\mathrm{HO}^{\bullet}}{\longrightarrow}(\mathrm{IV}) \stackrel{\text { fast }}{\longrightarrow} \mathrm{As}(\mathrm{V}) \\
\mathrm{H}_{3} \mathrm{AsO}_{3}+{ }^{3} \mathrm{CDOM}^{*} \rightarrow \mathrm{As}(\mathrm{V}) \\
\mathrm{As}(\mathrm{OH})_{2} \mathrm{O}^{-} \stackrel{\mathrm{HO}}{\rightarrow} \mathrm{As}(\mathrm{IV}) \stackrel{\text { fast }}{\longrightarrow} \mathrm{As}(\mathrm{V}) \\
\mathrm{As}(\mathrm{OH})_{2} \mathrm{O}^{-} \stackrel{\mathrm{CO}_{3}^{-}}{\longrightarrow} \mathrm{As}(\mathrm{IV}) \stackrel{\text { fast }}{\longrightarrow} \mathrm{As}(\mathrm{V})
\end{gathered}
$$

Most of the relevant second-order reaction rate constants are available in the literature but, because the rate constant of $\mathrm{As}(\mathrm{OH})_{2} \mathrm{O}^{-}+\mathrm{HO}^{\bullet}$ is not known, we assumed it to be equal to the corresponding $\mathrm{H}_{3} \mathrm{AsO}_{3}$ rate constant. This assumption is supported by the fact that, according to Kim et al. [16], the phototransformation rate of $\mathrm{As}(\mathrm{III})$ by $\mathrm{HO} \mathrm{O}^{\bullet}$ in the $4.5-12 \mathrm{pH}$ interval is mostly affected by [HO$\left.{ }^{\bullet}\right]$ variations and much less by the speciation of As(III). The total phototransformation rate of As(III) $\left(R_{A s(I I I)}^{\text {tot }}\right)$ can be written as the sum of the separate rates of Reactions (6-9), as follows:

$$
R_{A s(I I I)}^{t o t}=R_{\mathrm{H}_{3} \mathrm{AsO}_{3}}^{\mathrm{HO}^{\bullet}}+R_{\mathrm{H}_{3} \mathrm{AsO}_{3}}^{3 \mathrm{CDOM}^{*}}+R_{A s(\mathrm{OH})_{2} \mathrm{O}^{-}}^{\mathrm{HO}}+R_{\mathrm{As}(\mathrm{OH})_{2} \mathrm{O}^{-}}^{\mathrm{CO}_{3}^{\bullet-}}
$$

where $R_{A s(I I I)}^{i}=k_{A s(I I I)}^{i}[A s(I I I)][i], i=\mathrm{HO}^{\bullet},{ }^{3} \mathrm{CDOM}^{*}$ or $\mathrm{CO}_{3}{ }^{\bullet-}$, and $\mathrm{As}(\mathrm{III})=\mathrm{H}_{3} \mathrm{AsO}_{3}$ or $\mathrm{As}(\mathrm{OH})_{2} \mathrm{O}^{-}$. By introducing Equations (4) and (5) in Equation (10) and by dividing for [As(III) $]_{\text {tot, }}$ one obtains:

$$
k_{A s(I I I)}^{\text {tot }}=\alpha_{\mathrm{H}_{3} \mathrm{AsO}_{3}}\left(k_{\mathrm{H}_{3} \mathrm{AsO}_{3}}^{\mathrm{HO}_{3}}\left[\mathrm{HO} \mathrm{O}^{\bullet}\right]+k_{\mathrm{H}_{3} A s \mathrm{O}_{3}}^{3}\left[{ }^{*} \mathrm{CDOM}^{*}\right]\right)+\alpha_{\mathrm{As}(\mathrm{OH})_{2} \mathrm{O}^{-}}\left(k_{\mathrm{As}(\mathrm{OH})_{2} \mathrm{O}^{-}}^{\mathrm{HO}}\left[\mathrm{HO}^{\bullet}\right]+k_{A s(\mathrm{OH})_{2} \mathrm{O}^{-}}^{\mathrm{CO}^{\bullet-}}\left[\mathrm{CO}_{3}^{\bullet-}\right]\right)
$$

where $k_{A s(I I I)}^{t o t}=R_{A s(I I I)}^{t o t}\left([A s(I I I)]_{t o t}\right)^{-1}$ is the overall pseudo-first order rate constant of As(III) oxidation. Since $k_{A s(I I I)}^{\text {tot }}$ contains the terms $\alpha_{\mathrm{H}_{3} \mathrm{AsO}_{3}}$ and $\alpha_{\mathrm{As}(\mathrm{OH})_{2} \mathrm{O}^{-}}$, it is a function of $\mathrm{pH}$ as suggested by Equations (4) and (5).

The steady-state $\left[\mathrm{CO}_{3}{ }^{\bullet-}\right]$ obviously depends on the value of ${k^{3} \mathrm{COOM}_{3}^{*-}}^{*}$, for which different estimates are available [23]. The take the different possibilities into account, $\left[\mathrm{CO}_{3}{ }^{\bullet-}\right]$ was calculated as follows:

$$
\left[\mathrm{CO}_{3}^{\bullet-}\right]=\frac{\left[\mathrm{HO}^{\bullet}\right]\left(k_{\mathrm{HCO}_{3}^{-}}^{\mathrm{HO}}\left[\mathrm{HCO}_{3}^{-}\right]+k_{\mathrm{CO}_{3}^{2-}}^{\mathrm{HO}}\left[\mathrm{CO}_{3}^{2-}\right]\right)+k_{\mathrm{CO}_{3}^{2-}}^{3 \mathrm{CDOM}^{*}}\left[{ }^{3} \mathrm{CDOM}^{*}\right]\left[\mathrm{CO}_{3}^{2-}\right]}{k_{D O M}^{\mathrm{CO}_{3}^{\bullet-}} \mathrm{DOC}}
$$

where $\left[\mathrm{HO}^{\bullet}\right]$ and $\left[3 \mathrm{CDOM}^{*}\right]$ were provided by APEX, $k_{\mathrm{HCO}_{3}^{-}}^{\mathrm{HO}}=8.5 \times 10^{6} \mathrm{M}^{-1} \cdot \mathrm{s}^{-1}$, and $k_{\mathrm{CO}_{3}^{--}}^{\mathrm{HO}}=3.9 \times$ $10^{8} \mathrm{M}^{-1} \cdot \mathrm{s}^{-1}$ [33]. Moreover, $k_{D O M}^{C O_{3}^{\bullet-}}=10^{2} \mathrm{~L} \cdot(\mathrm{mg} \cdot \mathrm{C})^{-1} \cdot \mathrm{s}^{-1}$ is the second-order rate constant of $\mathrm{CO}_{3} \cdot-$ scavenging by DOM.

\section{Conclusions}

Photochemical modelling suggests that As(III) would undergo photooxidation in paddy floodwater and, at $\mathrm{pH}<8.5$, mainly upon reaction with ${ }^{3} \mathrm{CDOM}^{*}$ and $\mathrm{HO}^{\bullet}$. Note that $\mathrm{As}(\mathrm{III})$ oxidation by irradiated CDOM likely involves phenoxy radicals or other species to a higher extent than ${ }^{3} \mathrm{CDOM}^{*}$; thus, our approach can underestimate the importance of photochemical reactions. The predicted half-life times $t_{1 / 2}$ were much lower in May compared to June and July because, in the latter months, the rice plant growth would produce an important sunlight-shielding effect by the canopy. Therefore, As(III) photooxidation can be neglected in June and July. When typical chemical composition data of 
paddy water in May are taken into account, one obtains As(III) half-life times in the range of 20-30 days. In this case, photochemical As(III) oxidation could be overcome by microbial As(V) reduction to As(III). However, the photooxidation of $\mathrm{As}$ (III) might be much faster at $\mathrm{pH}>8.5$ if the carbonate radicals, $\mathrm{CO}_{3}{ }^{\bullet-}$, were produced efficiently by the reaction between ${ }^{3} \mathrm{CDOM}^{*}$ and $\mathrm{CO}_{3}{ }^{2-}$. Much depends on the $k_{\mathrm{CO}_{3}^{3}}^{3 \mathrm{CDOM}^{*}}$ second-order rate constant: if it is around $10^{6} \mathrm{M}^{-1} \cdot \mathrm{s}^{-1}$ or higher, the production of $\mathrm{CO}_{3}{ }^{\bullet-}$ and the subsequent reaction between $\mathrm{CO}_{3}{ }^{\bullet-}$ and $\mathrm{As}(\mathrm{OH})_{2} \mathrm{O}^{-}$can play a key role in $\mathrm{As}(\mathrm{III})$ photooxidation. Further work is needed to better understand the $\mathrm{CO}_{3}{ }^{\bullet-}$ formation processes in paddy water concerning, most notably, the $\mathrm{CO}_{3}{ }^{\bullet-}$ formation quantum yield at basic $\mathrm{pH}$ and the ${k_{C}^{3} \mathrm{CDOM}_{3}^{2-}}^{*}$ rate constant.

Acknowledgments: Financial support by Università di Torino-Ricerca Locale is gratefully acknowledged.

Author Contributions: D.V. conceived the study and corrected the paper; L.C. elaborated the model, carried out the model calculations, and wrote the first draft of the paper.

Conflicts of Interest: The authors declare no conflict of interest. The funding sponsors had no role in the design of the study; in the collection, analyses, or interpretation of data; in the writing of the manuscript, and in the decision to publish the results.

\section{References}

1. Ahmed, M.F.; Ahuja, S.; Alauddin, M.; Hug, S.J.; Lloyd, J.R.; Pfaff, A.; Pichler, T.; Saltikov, C.; Stute, M.; van Geen, A. Ensuring safe drinking water in Bangladesh. Science 2006, 314, 1687-1688. [CrossRef] [PubMed]

2. Garnier, J.-M.; Travassac, F.; Lenoble, V.; Rose, J.; Zheng, Y.; Hossain, M.S.; Chowdhury, S.H.; Biswas, A.K.; Ahmed, K.M.; Cheng, Z.; et al. Temporal variations in arsenic uptake by rice plants in Bangladesh: The role of iron plaque in paddy fields irrigated with groundwater. Sci. Total Environ. 2010, 408, 4185-4193. [CrossRef] [PubMed]

3. Otero, X.L.; Tierra, W.; Atiaga, O.; Guanoluisa, D.; Nunes, L.M.; Ferreira, T.O.; Ruales, J. Arsenic in rice agrosystems (water, soil and rice plants) in Guayas and Los Ríos provinces, Ecuador. Sci. Total Environ. 2016, 573, 778-787. [CrossRef] [PubMed]

4. Abedin, M.J.; Feldmann, J.; Meharg, A.A. Uptake kinetics of arsenic species in rice plants. Plant Physiol. 2002, 128, 1120-1128. [CrossRef] [PubMed]

5. Zhao, F.-J.; Zhu, Y.-G.; Meharg, A.A. Methylated arsenic species in rice: Geographical variation, origin, and uptake mechanisms. Environ. Sci. Technol. 2013, 47, 3957-3966. [CrossRef] [PubMed]

6. Campbell, K.M.; Nordstrom, D.K. Arsenic speciation and sorption in natural environments. Rev. Mineral. Geochem. 2014, 79, 185-216. [CrossRef]

7. Takahashi, Y.; Minamikawa, R.; Hattori, K.H.; Kurishima, K.; Kihou, N.; Yuita, K. Arsenic behavior in paddy fields during the cycle of flooded and non-flooded periods. Environ. Sci. Technol. 2004, 38, 1038-1044. [CrossRef] [PubMed]

8. Zheng, R.L.; Sun, G.X.; Zhu, Y.G. Effects of microbial processes on the fate of arsenic in paddy soil. Chin. Sci. Bull. 2013, 58, 186-193. [CrossRef]

9. Macur, R.E.; Jackson, C.R.; Botero, L.M.; McDermott, T.R.; Inskeep, W.P. Bacterial populations associated with the oxidation and reduction of arsenic in an unsaturated soil. Environ. Sci. Technol. 2004, 38, 104-111. [CrossRef] [PubMed]

10. Oremland, R.S.; Stolz, J.F. The ecology of arsenic. Science 2003, 300, 939-944. [CrossRef] [PubMed]

11. Soda, S.O.; Yamamura, S.; Zhou, H.; Ike, M.; Fujita, M. Reduction kinetics of As(V) to As(III) by a dissimilatory arsenate-reducing bacterium, Bacillus sp. SF-1. Biotechnol. Bioeng. 2006, 93, 812-815. [CrossRef] [PubMed]

12. Macur, R.E.; Wheeler, J.T.; McDermott, T.R.; Inskeep, W.P. Microbial populations associated with the reduction and enhanced mobilization of arsenic in mine tailings. Environ. Sci. Technol. 2001, 35, 3676-3682. [CrossRef] [PubMed]

13. Hellweger, F.L.; Lall, U. Modeling the effect of algal dynamics on arsenic speciation in Lake Biwa. Environ. Sci. Technol. 2004, 38, 6716-6723. [CrossRef] [PubMed] 
14. Vione, D.; Minella, M.; Maurino, V.; Minero, C. Indirect photochemistry in sunlit surface waters: Photoinduced production of reactive transient species. Chem. Eur. J. 2014, 20, 10590-10606. [CrossRef] [PubMed]

15. K1aning, U.K.; Bielski, B.H.J.; Sehested, K. Arsenic(IV). A pulse-radiolysis study. Inorg. Chem. 1989, 28, 2717-2724.

16. Kim, D.-H.; Lee, J.; Ryu, J.; Kim, K.; Choi, W. Arsenite oxidation initiated by the UV photolysis of nitrite and nitrate. Environ. Sci. Technol. 2014, 48, 4030-4037. [CrossRef] [PubMed]

17. Dutta, P.K.; Pehkonen, S.O.; Sharma, V.K.; Ray, A.K. Photocatalytic oxidation of arsenic(III): Evidence of hydroxyl radicals. Environ. Sci. Technol. 2005, 39, 1827-1834. [CrossRef] [PubMed]

18. Buschmann, J.; Canonica, S.; Lindauer, U.; Hug, S.J.; Sigg, L. Photoirradiation of dissolved humic acid induces arsenic(III) oxidation. Environ. Sci. Technol. 2005, 39, 9541-9546. [CrossRef] [PubMed]

19. Brockbank, C.I.; Batley, G.E.; Low, G.K.-C. Photochemical decomposition of arsenic species in natural waters. Environ. Technol. Lett. 1988, 9, 1361-1366. [CrossRef]

20. Kurasawa, H. The weekly succession in the standing crop of plankton and zoobenthos in the paddy field. Parts 1 and 2. Bull. Res. Sci. Jpn. 1956, 41-42, 86-98.

21. Quesada, A.; Leganés, F.; Fernàndez-Valiente, E. Environmental factors controlling N2 fixation in Mediterranean rice fields. Microb. Ecol. 1997, 34, 39-48. [CrossRef] [PubMed]

22. Graeber, D.; Goyenola, G.; Meerhoff, M.; Zwirnmann, E.; Ovesen, N.B.; Glendell, M.; Gelbrecht, J.; de Mello, F.T.; Gonzalez-Bergonzoni, I.; Jeppesen, E.; et al. Interacting effects of climate and agriculture on fluvial DOM in temperate and subtropical catchments. Hydrol. Earth Syst. Sci. 2015, 19, 2377-2394. [CrossRef]

23. Canonica, S.; Kohn, T.; Mac, M.; Real, F.J.; Wirz, J.; von Gunten, U. Photosensitizer method to determine rate constants for the reaction of carbonate radical with organic compounds. Environ. Sci. Technol. 2005, 39, 9182-9188. [CrossRef] [PubMed]

24. Carena, L.; Minella, M.; Barsotti, F.; Brigante, M.; Milan, M.; Ferrero, A.; Berto, S.; Minero, C.; Vione, D. Phototransformation of the herbicide propanil in paddy field water. Environ. Sci. Technol. 2017, 51, 2695-2704. [CrossRef] [PubMed]

25. Coelho, C.; Guyot, G.; ter Halle, A.; Cavani, L.; Ciavatta, C.; Richard, C. Photoreactivity of humic substances: Relationship between fluorescence and singlet oxygen production. Environ. Chem. Lett. 2011, 9, 447-451. [CrossRef]

26. Bodrato, M.; Vione, D. APEX (Aqueous Photochemistry of Environmentally occurring Xenobiotics): A free software tool to predict the kinetics of photochemical processes in surface waters. Environ. Sci. Process. Impacts 2014, 16, 732-740. [CrossRef] [PubMed]

27. Fabbri, D.; Minella, M.; Maurino, V.; Minero, C.; Vione, D. Photochemical transformation of phenylurea herbicides in surface waters: A model assessment of persistence, and implications for the possible generation of hazardous intermediates. Chemosphere 2015, 119, 601-607. [CrossRef] [PubMed]

28. Bianco, A.; Fabbri, D.; Minella, M.; Brigante, M.; Mailhot, G.; Maurino, V.; Minero, C.; Vione, D. New insights into the environmental photochemistry of 5-chloro-2-(2,4-dichlorophenoxy)phenol (triclosan): Reconsidering the importance of indirect photoreactions. Water Res. 2015, 72, 271-280. [CrossRef] [PubMed]

29. De Laurentiis, E.; Prasse, C.; Ternes, T.A.; Minella, M.; Maurino, V.; Minero, C.; Sarakha, M.; Brigante, M.; Vione, D. Assessing the photochemical transformation pathways of acetaminophen relevant to surface waters: Transformation kinetics, intermediates, and modelling. Water Res. 2014, 53, 235-248. [CrossRef] [PubMed]

30. Marchetti, G.; Minella, M.; Maurino, V.; Minero, C.; Vione, D. Photochemical transformation of atrazine and formation of photointermediates under conditions relevant to sunlit surface waters: Laboratory measures and modelling. Water Res. 2013, 47, 6211-6222. [CrossRef] [PubMed]

31. Saito, M.; Watanabe, I. Organic matter production in rice field flood water. Soil Sci. Plant Nutr. 1978, 24, 427-440. [CrossRef]

32. Roger, P.A. Biology and Management of the Floodwater Ecosystem in Rice Fields; International Rice Research Institute: Manila, Philippines, 1996; pp. 7-14. 
33. Buxton, G.V.; Greenstock, C.L.; Helman, W.P.; Ross, A.B. Critical review of rate constants for reactions of hydrated electrons, hydrogen atoms and hydroxyl radicals $\left({ }^{\bullet} \mathrm{OH} / \mathrm{O}^{-\bullet}\right)$ in aqueous solution. J. Phys. Chem. Ref. Data 1988, 17, 513-886. [CrossRef]

Sample Availability: No samples were used in this work. article distributed under the terms and conditions of the Creative Commons Attribution (CC BY) license (http:/ / creativecommons.org/licenses/by/4.0/). 